\title{
ЛЕКСИКО-СТИЛІСТИЧНІ ОЗНАКИ КОНФЕСІЙНОЇ СФЕРИ В АНГЛІЙСЬКІЙ ТА УКРАЇНСЬКІЙ МОВАХ: ЗІСТАВНИЙ АСПЕКТ (ЧАСТИНА 2)
}

\author{
Леонід Черноватий \\ Харківський наџіональний університет імені В. Н. Каразіна, \\ Майдан Свободи, 4, м. Харків, Украӥна, 61022 \\ leonid.m.chernovaty@meta.ua
}

Грунтуючись на результатах порівняльного стилістичного аналізу англо- й українськомовного текстів перекладу першого розділу книги “Буття” Біблії, ми встановили їхні спільні й відмінні лексикостилістичні характеристики, які можуть враховуватися у змісті навчання зіставних лексикології та стилістики, а також перекладу текстів конфесійного стилю. За результатами порівняння лексикостилістичних засобів згаданих текстів сформульовано попередні висновки про достатньо високий ступінь їх схожості в цьому аспекті. На основі одержаних даних сформульовано загальний висновок про дещо більшу варіативність лексико-стилістичних засобів в українському тексті, яку можна пояснити різними стандартами стилістичної прийнятності в двох мовах і культурах.

Ключові слова: англійська й українська мови, Біблія (книга “Буття”), зіставна лексикологія, зіставна стилістика, конфесійний стиль, лексико-стилістичні характеристики, навчання перекладу, порівняльний лексико-стилістичний аналіз.

Вступ. У першій частині цього повідомлення [12] зазначалися важливість фонових знань як компонента фахової компетентності перекладача (ФКП) (див. [10]) та необхідність максимального наближення обсягу згаданих знань перекладача до того, яким володіє пересічний освічений носій відповідної мови. За результатами аналізу літератури [17]), було встановлено, що одним із обов' язкових компонентів таких знань є конфесійна сфера, важливою складовою якої (принаймні для носіїв української та англійської мов) є Біблія та дотичні поняття. Було зауважено, що крім фонових знань, важливим є також наявність у структурі ФКП конфесійних термінів для маркування відповідних понять як у мові оригіналу, так і в мові перекладу, а також умінь дотримання конфесійного стилю, що характеризується чіткими ознаками в кожній мові. Формування таких умінь, так само як і усвідомлення названих ознак, було віднесено до завдань порівняльної стилістики (мов, що контактують у перекладі), яка тлумачиться як виявлення співвідношення спільного і національно-специфічного у кожній з таких мов [6, с. 26].

Аналіз останніх досліджень і публікацій. У попередній публікації [12] констатувалася незначна кількість розвідок $[4 ; 6 ; 7 ; 14 ; 16]$ у сфері, що розглядається.

(C) Черноватий Л., 2021 
Зокрема, згадувалися дослідження церковної титулатури [8], функцій повтору [1; 5], прагматичних функцій біблеїзмів у політичних англомовних промовах [13], можливостей використання теорії релевантності для аналізу англомовних текстів перекладу (АМ ТП) українськомовних конфесійних текстів [15], загальні особливості перекладу конфесійних текстів в англійській та українській мовах [11].

У першій частині цієї статті подано опис порівняльного аналізу паралельних текстів віршів 1-13 першого розділу книги "Буття" (Genesis), найвідоміших текстів перекладу (ТП) Старого Заповіту (Old Testament) англійською [18] та українською [2] мовами. За результатами згаданого аналізу було сформульовано попередній висновок про значну лексико-стилістичну схожість проаналізованих фрагментів. Зокрема, в обох текстах виявлено (за деякими винятками) значні збіги номенклатури маркованих лексем, повторів та лексико-стилістичного наповнення; синхронне вживання градації й ампліфікації, а також полісиндетону. Схожим виявилося також систематичне, хоч і не завжди паралельне, вживання незвичних для певного контексту лексем, включаючи архаїзми. Виявлені відмінності включали систематичне вживання дієслова стану (be) в АМ ТП там, де в українськомовних текстах перекладу (УМ ТП) застосовуються дієслова переходу з одного стану до іншого; використання в АМ ТП однотипних метафор, тоді як в УМ ТП у цьому випадку вжито нейтральні лексеми; застосування в УМ ТП слів підвищеного стилю, а в АМ ТП - нейтральної лексеми; парцеляція в АМ ТП з наголошенням парцеляту, тоді як в УМ ТП тут спостерігається парний зв'язок синонімів; персоніфікація в АМ ТП, з одного боку, та алітерація й асонанс в УМ ТП, з іншого (детальніше - див. [12]).

Методологія дослідження. Як уже зазначалася в першій частині цього повідомлення [12], метою цієї розвідки є аналіз порівняльних лексико-стилістичних ознак конфесійного стилю в двох мовах на матеріалі паралельних текстів першого розділу книги "Буття" (Genesis) англійською [18] та українською [2] мовами, перекладених 3 одного й того ж тексту оригіналу (ТО) третьою (давньогебрейською та арамейською) мовою. У першій частині звіту про проведене дослідження [12] вибір для аналізу двох ТП (без врахування ТО) обгрунтовувався тим, що на сьогодні обидва ТП функціонують як самостійні тексти, незалежно від ступеня повноти їх відповідності ТО. Отже, при перекладі похідних від Біблії текстів (проповіді тощо) англійською чи українською перекладач має враховувати лексико-стилістичні особливості конфесійного стилю згаданих мов, ігноруючи співвіднесеність обох ТП з ТО.

Як уже згадувалося в попередніх публікаціях [9; 12], зміст першого розділу книги "Буття" (Genesis) викладається в шести періодах, тобто гармонійно організованих багатокомпонентних синтаксичних конструкціях, які замикаються в коло, утворюючи завершені в логічному й інтонаційному плані одиниці мови [1; 4-7], де перша частина періоду містить повторювані однорідні компоненти 3 однотипними зачинами, а друга - завершує думку [6, с. 229]. В попередній публікації розглянуто перші три періоди (вірші 3-13) (детальніше - див [12]), а далі подано результати порівняльного аналізу заключних трьох періодів (вірші 14-31) згаданих паралельних текстів. 
Результати дослідження та їхнє обгрунтування.

\section{Вірші 14 і 15 першого розділу книги "Буття"}

Таблиия 6

\begin{tabular}{|l|l|}
\hline 14. And God said, Let there be lights in the & 14. I сказав Бог: Нехай будуть світила на \\
firmament of the heaven to divide the day from & тверді небесній для відділення дня від ночі, \\
the night; and let them be for signs, and for & $i$ нехай вони стануть знаками, і часами \\
seasons, and for days, and years. 15. And let & умовленими, і днями, і роками. 15. I нехай \\
them be for lights in the firmament of the heaven & вони стануть на тверді небесній світилами, \\
to give light upon the earth: and it was so. & щяоб світити над землею. I сталося так. \\
\hline
\end{tabular}

У віршах 14 і 15 в УМ ТП доцільно зазначити вибір дієслова переходу з одного стану до іншого (“ставати знаками”, “ставати світилами”) для понять, що в АМ ТП передано дієсловом стану (be signs; be for lights) в обох віршах. Ще однією відмінністю $\epsilon$ вибір інфінітивної структури для передачі мети в АМ ТП (to divide the day from the night) на відміну від УМ ТП, де застосовується віддієслівний іменник (для відділення дня від ночi), що посилює номінативність та офіційність українського тексту. В інших випадках зазначення мети в АМ ТП здійснюється за допомогою прийменника for (let them be for signs, and for seasons, and for days, and years), що дає змогу застосувати повтор, а в УМ ТП - орудним відмінком іменника у сполученні з дієсловом переходу з одного стану до іншого (“ставати світилами”), де повтор неможливий. Варто згадати, що в одному випадку спосіб передачі мети (за допомогою інфінітива) збігається в обох текстах (to give light - "щоб світити”). Спостерігається відмінність у передачі поняття, яке в АМ ТП передано словом seasons, а в УМ ТП - парафразою “часами умовленими”. Оскільки в АМ ТП лексема seasons стоїть в ряду понять days та years, то можна припустити, що мова йде про пори року. Загалом “часи умовлені" можна тлумачити як “пори року", однак у цьому випадку слід зробити висновок, що спосіб їх позначення у двох текстах $\epsilon$ принципово відмінним i, якщо говорити про УМ ТП, то він $є$ опоетизованим. Як і в попередніх випадках, обидва аналізовані вірші пронизує полісиндетон.

Таблиия 7

\section{Вірші 16-19 першого розділу книги "Буття"}

\begin{tabular}{|c|c|}
\hline $\begin{array}{l}\text { 16. And God made two great lights; the greater } \\
\text { light to rule the day, and the lesser light to rule } \\
\text { the night: he made the stars also. 17. And God } \\
\text { set them in the firmament of the heaven to give } \\
\text { light upon the earth, } 18 \text {. And to rule over the } \\
\text { day and over the night, and to divide the light } \\
\text { from the darkness: and God saw that it was } \\
\text { good. 19. And the evening and the morning } \\
\text { were the fourth day. }\end{array}$ & $\begin{array}{l}\text { 16. І вчинив Бог обидва світила великі, } \\
\text { світило велике, щьоб воно керувало днем, } \\
\text { світило мале, щоб керувало ніччю, також } \\
\text { зорі. 17. І Бог умістив їх на тверді небесній, } \\
\text { щуоб світили вони над землею, 18. і шчоб } \\
\text { керували днем та ніччю, і щоб відділювали } \\
\text { світло від темряви. I Бог побачив, щчо } \\
\text { це добре. 19. I був вечір, і був ранок, день } \\
\text { четвертий. }\end{array}$ \\
\hline
\end{tabular}

У вірші 16 в обох текстах має місце персоніфікація, тобто метафоричне перенесення ознак істот на неістот [6, с. 446]: (to rule the day - “керувати днем”, to 
rule the night - “керувати ніччю”), що надає поетичності викладу. Ще однією фігурою якості, що застосовується в обох текстах у цьому вірші, є парафраза, тобто непряма згадка об'єкта шляхом опису [6, с. 446]: the greater light to rule the day - "світило велике, щоб воно керувало днем", тобто “сонце”, а також the lesser light to rule the night - “світило мале, щоб керувало ніччю”, тобто "місяць”. Безумовно, що згадані прийоми значно покращують орнаментацію тексту. Тут спостерігаються ще й різноманітні повтори: lights - light - light (світила - світило - світило), to rule the day - to rule the night ("щобо... керувало днем, щьоб керувало ніччю”), а також антитеза, тобто підкреслене зіставлення протилежних, але пов'язаних між собою понять для підсилення враження [6, с. 433]: the greater light - the lesser light.

Висхідна градація у віршах 17 і 18 в обох текстах досягається повтором інфінітивних конструкцій, що позначають мету створення двох світил. В АМ ТП зовнішня ознака повтору забезпечується часткою to (to give light $<_{\ldots} . .>$, to rule $<\ldots>$, to divide <..>), а в УМ ТП - сполучником “щоб” (“щоб світили < ..>, і щоб керували $<$..>, і шоб відділювали < ..>”). Послідовність лексем у повторах нагнітає експресію, аж поки та вишукано розряджається у заключній фразі: and God saw that it was good (“І Бог побачив, що це добре”). Остаточно довершує цю гармонійну конструкцію рефрен у вірші 19.

Таблиия 8

Вірші 20-23 першого розділу книги “Буття"

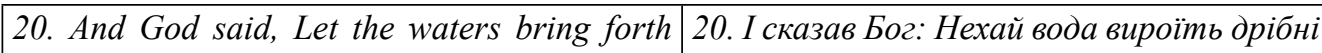
abundantly the moving creature that hath life, icтоти, душу живу, i птаство, щя літає and fowl that may fly above the earth in the open над землею під небесною твердю. 21. I firmament of heaven. 21. And God created great створив Бог риби великі, і всяку душу whales, and every living creature that moveth, живу плазуючу, щзо ї̈ вода вироїла за їх which the waters brought forth abundantly, родом, і всяку пташину крилату за родом after their kind, and every winged fowl after ï̈. I Бог побачив, щзо добре воно. 22. I his kind: and God saw that it was good. поблагословив їх Бог, кажучи: Плодіться 22. And God blessed them, saying, Be fruitful, $\check{u}$ розмножуйтеся, $i$ наповнюйте воду в and multiply, and fill the waters in the seas, морях, а птаство нехай розмножується and let fowl multiply in the earth. 23. And the на землі! 23. I був вечір, і був ранок, день evening and the morning were the fifth day. n'ятий.

У вірші 20 в АМ ТП спостерігається парафраза - the moving creature that hath life (маються на увазі будь-які живі істоти, крім тих, що літають, див. далі) та fowl (тобто будь-які істоти, що літають). Доцільно відзначити також вживання книжної лексики (abundantly, firmament, heaven) та архаїзму hath. УМ ТП відзначається складнішими лексико-стилістичними ознаками, зокрема, це стосується застосування парафрази: словосполучення “душа жива”, вірогідно, вживається для позначення “живої істоти”, оскільки поняття “душа" в конфесійному дискурсі традиційно стосується головно людини. Звертає на себе увагу варіативність способів застосування означень у цьому вірші (препозитивне (“дрібні істоти”), постпозитивне (“душа жива”) та за 
допомогою підрядного звороту (“що літає над землею”), що безумовно прикрашає виклад. Книжна лексика (“небесна твердь”), вживання збірного іменника “птаство” та метафоричне використання лексеми “вироїти” (виконувати у великій кількості, масово, безперервно, сильно [3, с. 1085]) створюють ефект урочистості й стилізують виклад під старовину.

У вірші 21 в АМ ТП бачимо вживання архаїзму moveth у складі парафрази - the living creature that moveth (будь-які живі істоти, крім тих, що літають) та winged fowl, де лексема winged створює ефект тавтологічного повтору, оскільки у попередньому вірші слово fowl передавало те саме значення без будь-якого означення. УМ ТП, знову ж таки, характеризується ширшим діапазоном лексико-стилістичних засобів: вживанням метафори “вироїти”, стилістично забарвлених лексем “плазуюча", “пташина крилата” та парафраз - “душа жива плазуюча” (жива істота, крім тих, що не літають), “пташина крилата” (живі істоти, що літають), вживанням родового поняття "риба" замість видового “кит” в англомовному варіанті. Яскравою особливістю цього вірша є розміщення в УМ ТП усіх означень у постпозиції (“риби великі”, “душа жива плазуюча", “пташина крилата”), крім лексеми “всяка”, яка, однак, повторюється двічі. Сукупність перелічених засобів утворює вірш, що характеризується привабливою стилістичною забарвленістю.

Вірш 22 в обох текстах має однакові лексико-стилістичні ознаки. Головним стилістичним елементом тут $є$ афоризм (короткий влучний вислів, який у стислій, зручній для запам'ятовування формі подає глибоку думку [6, с. 434]): Be fruitful, and multiply (“Плодіться й розмножуйтеся”); свою стилістичну роль відіграє й маркована (для конфесійного стилю) лексика: God (“Бог”) та bless (“благословляти”). Вживання збірного іменника “птаство” в УМ ТП посилює його образність. Характеристики рефрену (вірш 23) вже розглядалися раніше. Як і в попередніх випадках, усі аналізовані вірші пронизує полісиндетон.

\section{Вірші 24-27 першого розділу книги “Буття"}

Таблиия 9

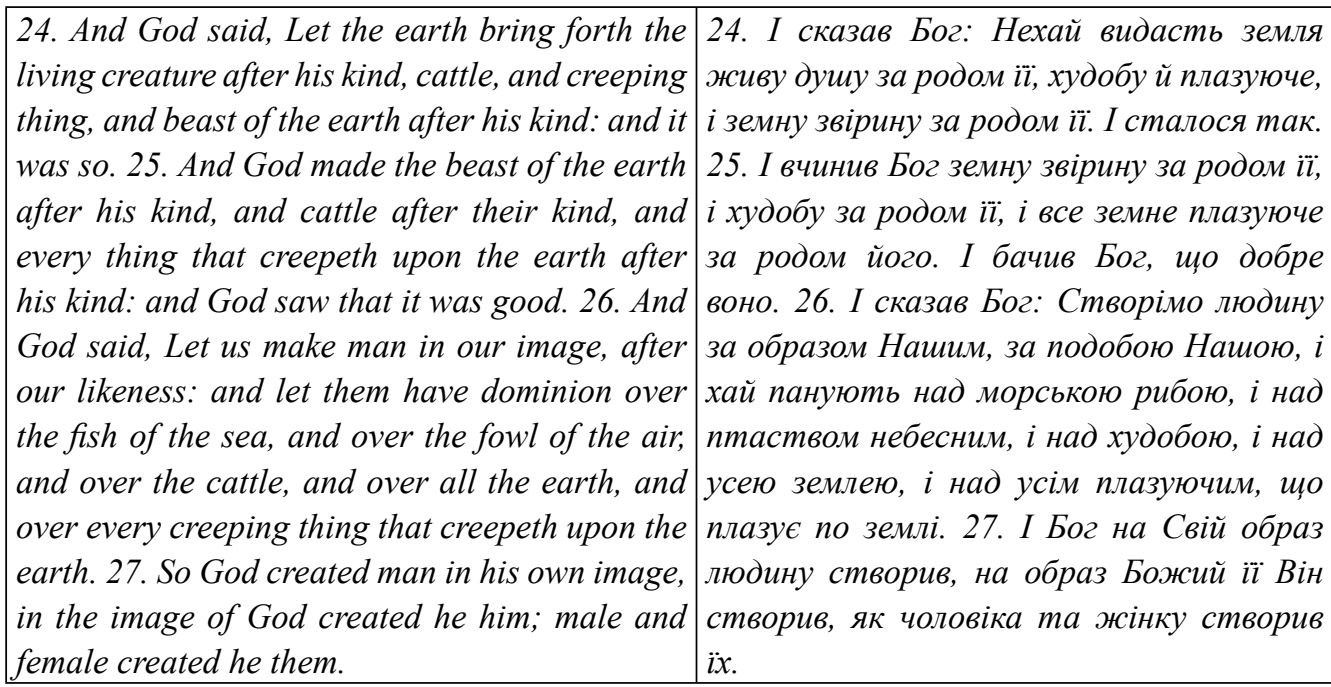


Перша половина останнього періоду розділу 1 (вірші 24-27) характеризується різноманітними повторами. Це передусім полісиндетон, що спостерігається в усіх аналізованих віршах. У вірші 24 бачимо повтор словосполучення after his kind (“за родом Пї”), а також парафрази - в АМ ТП це словосполучення the living creature (вжито в однині у родовому значенні, маються на увазі живі істоти, які далі деталізуються), creeping thing (вжито в однині, у родовому значенні - “плазуни"), beast of the earth (вжито так само в однині та в родовому значенні - "звірі"). Схожа картина має місце і в УМ ТП: парафраза - “жива душа” (у значенні “жива істота, але не людина”, вжито в однині), “плазуюче” (збірний субстантивований дієприкметник у значенні “плазуни”), "звірина" (збірний іменник у значенні “звірі”, також вжито в однині). В обох текстах у цьому вірші вжито стилістично забарвлену лексику: living creature (“жива душа"), creeping thing ("плазуюче"), beast of the earth (“звірина"), "видавати" (у значенні “породжувати").

Повтори продовжуються і у вірші 25 , де переспівуються більшість слів $\mathrm{i}$ словосполучень вірша 24, утворюючи висхідну градацію, кожен 3 трьох щаблів якої закінчується словосполученням after his kind (“за родом iі / його”), крок за кроком піднімаючи напругу, що врешті-решт розряджається у заключному реченні and God saw that it was good ("I бачив Бог, що добре воно").

Серед інших лексико-стилістичних ознак вірша 25 в АМ ТП варто відзначити вживання архаїзму creepeth, парафрази - every thing that creepeth upon the earth ("плазуни") та книжної лексики (beast of the earth, every thing). В УМ ТП також спостерігаються парафрази - "все земне плазуюче" (“плазуни”), “звірина” (збірний іменник - “звірі”) і стилістично забарвлена лексема “вчинив” (у значенні “створив”).

У вірші 26 в обох ТП перше речення, що має форму риторичного звертання Господа до самого себе (Let us make man - "Створімо людину"), містить повтор у вигляді парафрази: значення словосполучення in our image (“за образом Нашим”) повторюється у перефразованому вигляді у наступному як after our likeness ("за подобою Нашою"). Друге спонукальне речення - let them have dominion ("хай панують”) - вміщує п’ятикратний повтор прийменника over перед кожним 3 однорідних членів речення: over the fish of the sea, and over the fowl of the air, and over the cattle, and over all the earth, and over every creeping thing ("над морською рибою, і над птаством небесним, і над худобою, і над усею землею, і над усім плазуючим"), що підкреслює важливість змісту кожного з таких членів [7, с. 192]. Більше того, перед кожним прийменником over повторюється ще й сполучник and (“i”), так само, як і на початку слів автора та перед другим спонукальним реченням, що свідчить про застосування посиленого полісиндетону. Експресивність викладу употужнюється завдяки паралелізму конструкцій однорідних членів в АМ ТП: конструкції з прийменником of - fish of the sea, fowl of the air, з узагальнювальними словами в обох ТП - all the earth, every creeping thing ("над усею землею, і над усім плазуючим"), а також тавтологічному повтору одного компонента попередньої строфи разом 3 його означеннями every creeping thing that creepeth upon the earth ("усім плазуючим, що плазує по землі”), що додатково пов'язує цю строфу з попередньою. Серед інших стилістичних засобів варто зазначити застосування в обох ТП антитези 
- підкресленого зіставлення протилежних, але пов'язаних між собою понять: fish of the sea, fowl of the air (“морська риба", "птаство небесне") для підсилення враження. У цьому вірші також бачимо афоризм - Let us make man in our image, after our likeness (“Створімо людину за образом Нашим, за подобою Нашою”), книжну лексику - have dominion (“панувати") та архаїзми creepeth в АМ ТП й “усею" - в УМ ТП.

У вірші 27 в АМ ТП у першому реченні (God created man in his own image) спостерігаємо багатофокусний повтор, тобто позначення референта різними словами [5], у цьому випадку - заміна нейтрального make на книжне create. Друге речення в обох ТП містить парафрази: слова God (“Бог”) і man (“людина") замінюються на he (“Він”) і him ("іiі”), a his own image (“Свій образ”) - на the image of God (“образ Божий”). Унаслідок застосування подвійного посиленого повтору лексеми created (“створив”) у сполученні $з$ іншими лексичними одиницями, частина 3 яких зберігається або замінюється на займенники, структура другого й третього речень має дуже виразне стилістичне забарвлення. В обох ТП спостерігається вживання книжної лексики: create, image, male, female в АМ ТП та “створювати”, “образ” в УМ ТП. В обох текстах є маркована лексика: God (“Бог”) та image of God (“образ Божий”).

\section{Вірші 28-31 першого розділу книги "Буття"}

Таблиия 10

\begin{tabular}{|c|c|}
\hline $\begin{array}{l}\text { 28. And God blessed them, and God said unto } \\
\text { them, Be fruitful, and multiply, and replenish } \\
\text { the earth, and subdue it: and have dominion } \\
\text { over the fish of the sea, and over the fowl of } \\
\text { the air, and over every living thing that moveth } \\
\text { upon the earth. 29. And God said, Behold, I } \\
\text { have given you every herb bearing seed, which } \\
\text { is upon the face of all the earth, and every tree, } \\
\text { in the which is the fruit of a tree yielding seed; } \\
\text { to you it shall be for meat. 30. And to every } \\
\text { beast of the earth, and to every fowl of the } \\
\text { air, and to every thing that creepeth upon the } \\
\text { earth, wherein there is life, I have given every } \\
\text { green herb for meat: and it was so. } 31 \text {. And } \\
\text { God saw every thing that he had made, and, } \\
\text { behold, it was very good. And the evening and } \\
\text { the morning were the sixth day. }\end{array}$ & 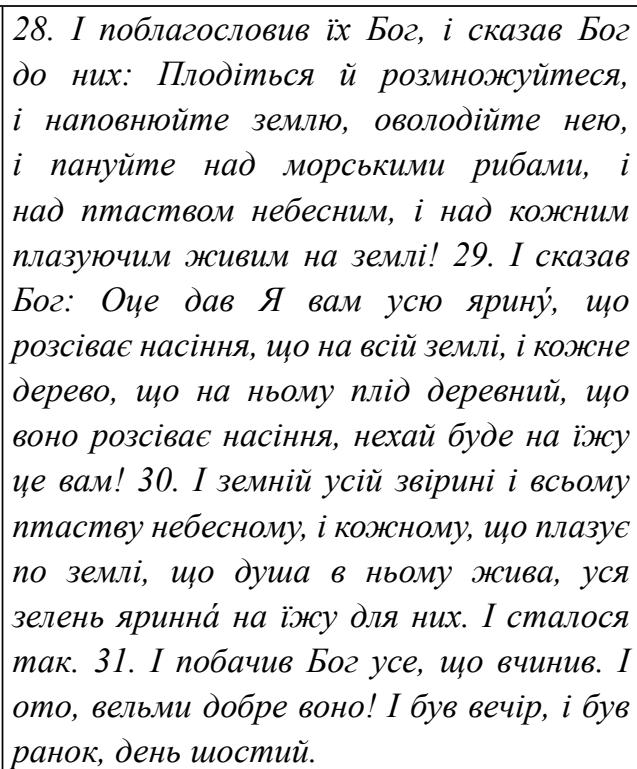 \\
\hline
\end{tabular}

Друга половина останнього періоду розділу 1 (вірші 28-31) завершує його. Як і в попередній частині цього періоду та розділі загалом, тут спостерігаються різноманітні повтори. У вірші 28 у словах автора бачимо тавтологічний повтор лексем God (“Бог”) i them (“ї/них"), який у сполученні зі зміною дієслова (said unto them замість blessed), посилює враження; повтор афоризму, що вже вживався у вірші 22 (Be fruitful, and multiply - "Плодіться й розмножуйтеся"), а також видозмінений повтор афоризму 
згаданого вірша (порівняйте, вірш 22: fill the waters in the seas - “наповнюйте воду в морях" та вірш 28: replenish the earth, and subdue it - "наповнюйте землю, оволодійте нею”). Третій афоризм - have dominion (“пануйте”) - містить повтори більшості лексем вірша 26 (порівняйте, вірш 26: over the fish of the sea, and over the fowl of the air, $<. .>$ and over every creeping thing - "над морською рибою, і над птаством небесним, $<\ldots>$ і над усім плазуючим" та вірш 28: over the fish of the sea, and over the fowl of the air, and over every living thing that moveth upon the earth - “над морськими рибами, і над птаством небесним, і над кожним плазуючим живим на землі!”).

Вірш 29 містить численні дослівні та видозмінені повтори лексем віршів 11 та 12 (див. [12]). Порівняйте, вірш 11 (див. [12]): the herb yielding seed (“ярину́, що насіння вона розсіває”), вірш 12 (див. [12]): herb yielding seed after his kind (“ярину́, що насіння розсіває за родом іï"), вірш 29: every herb bearing seed (“усю ярину́, що розсіває насіння"). Тут в АМ ТП у вірші 29, порівняно з віршом 11 (див. [12]), бачимо заміну лексеми yielding на bearing, а порівняно з віршем 12 (див. [12]) - певне лексичне спрощення, тоді як в УМ ТП у вірші 29, порівняно з віршом 11 (див. [12]), бачимо додавання узагальнюючого слова “усю”, яке суттєво посилює лексему “ярину́”, а 3 іншого боку - значне стилістичне послаблення, спричинене зменшенням загальної кількості слів (а з ним і втрату певних тропів) і застосуванням прямого порядку слів замість інверсії, що знижує рівень поетичності викладу.

Схоже спостерігається і стосовно іншого фрагмента, спільного для віршів, що розглядаються. Порівняйте, вірш 11 (див. [12]): fruit tree yielding fruit after his kind, whose seed is in itself (“дерево овочеве, що за родом своїм плід приносить, що в ньому насіння його”), вірш 12 (див. [12]): tree yielding fruit, whose seed was in itself, after his kind (“дерево, що приносить плід, що насіння його в нім за родом його”), вірш 29: every tree, in the which is the fruit of a tree yielding seed (“кожне дерево, що на ньому плід деревний, що воно розсіває насіння”). Тут в АМ ТП у вірші 29, порівняно з віршом 11, бачимо заміну означення fruit перед лексемою tree на узагальнюючий займенник every, який посилює означуване, видалення словосполучення after his kind, складне перефразування звороту tree yielding fruit <..> whose seed is in itself (наявне також, 3 невеликими відмінностями, і у вірші 12) на tree, in the which is the fruit of a tree yielding seed. Звертає на себе увагу незвичне вживання означеного артикля перед займенником (in the which), а також архаїчне Behold (замість звичнішого Look!). Це відповідним чином стилізує аналізований фрагмент. В АМ ТП у вірші 29 вжито метафору: face of all the earth (перенесення ознак істот на неістот), яка відсутня в УМ ТП (“на всій землі”), а також синекдоху (заміщення частиною цілого) - архаїчне вживання слова meat у значенні food (в УМ ТП вжито нейтральну лексему “іжа”).

3 іншого боку, в УМ ТП бачимо розмовне “Оце” (Behold), що наближує текст до просторічного стилю, марковану лексему “Я” (в значенні “Господь”), передану великою літерою, полісиндетон (чотирикратне повторення “що” на початку підрядних речень), який забезпечує градацію, де кожна наступна лексема посилює певне смислове чи експресивне значення [6, с. 435]. Інші лексичні особливості УМ ТП збігаються 3 тими, що притаманні віршам 11 і 12 (див. [12]): алітерація й асонанс (повтор приголосних та голосних у розташованих недалеко одне від одного словах [6, 
c. 433] (“насіння < ..> розсіває”), вживання стилістично забарвлених (архаїчних) слів: “ярина́" (у значенні “городина”, “овочі”) [3, с. 1424] і “дерево овочеве” (у значенні “дерево фруктове”) [3, с. 657].

Вірш 30 містить численні, хоч і дещо видозмінені повтори лексичних одиниць, що вже вживалися раніше (див. вірші 20, 24 і 25), і які характеризуються схожими стилістичними ознаками. В АМ ТП бачимо кілька випадків парафрази - beast of the earth (“будь-які живі істоти, крім птахів”) та fowl of the air (“птахи, що літають”), every thing that creepeth upon the earth (“будь-які живі істоти, що мешкають на суші”), wherein there is life (“живий”). Варто зазначити також вживання архаїзмів, які забезпечують ефект урочистості: beast (“тварина"), every thing (як два окремих слова, в сучасній мові їх пишуть разом), creepeth, wherein, meat (у значенні “їжа”).

Узагальнювальні означення, що посилюють стилістичний ефект означуваних елементів, вживаються в обох ТП, однак якщо в АМ ТП в усіх випадках застосовується лексема every (every beast, every fowl, every thing, every green herb), то в УМ ТП бачимо більшу варіативність, і не тільки фонетичну (“усій звірині”, “всьому птаству”, “кожному, що плазує”, “уся зелень яринна́”).

В УМ ТП парафраза вживається лише стосовно понять “живий” (“що душа в ньому жива”) та "плазуни” (“що плазує по землі”), тоді як для передачі інших лексичних одиниць, де ця фігура слова спостерігається в АМ ТП, вживаються збірні іменники “звірина”, “птаство”, “зелень”. Більша варіативність спостерігається в УМ ТП і стосовно способів застосування означень - якщо в АМ ТП бачимо головно постпозитивне їхнє розташування (beast of the earth, fowl of the air, thing that creepeth), що, зважаючи на переважно аналітичний характер англійської мови, ускладнює структуру словосполучення, то в УМ ТП наявні як препозитивні (“земна звірина”) й постпозитивні (“птаство небесне”, “зелень яринна́”) конструкції, так і підрядні звороти (“кожному, що плазує по землі”, “кожному, що душа в ньому жива”).

В усіх чотирьох віршах обох ТП застосовується полісиндетон. У вірші 28 він $є$ посиленим - повтор прийменника over (“над”) та сполучника and (“i”) перед кожною однорідною лексемою (and multiply, and replenish, and subdue; and have dominion over the fish, and over the fowl, and over every living thing. - "і розмножуйтеся, і наповнюйте; і пануйте над рибами, і над птаством, і над кожним плазуючим”). В АМ ТП вірша 29 маємо справу вже з послабленою його формою (every... every, which... in the which), тоді як в УМ ТП він функціонує повноцінно ("що розсіває насіння”, “що на всій землі”, “що на ньому плід”, “що воно розсіває”). В останніх двох віршах спостерігається однакова реалізація полісиндетону в обох текстах - вірш 30: And to every beast <...>, and to every fowl $<\ldots>$, and to every thing $<\ldots>$, and it was so. - "I $<\ldots>$ звірині, $\mathrm{i}<\ldots>$ птаству, і кожному <...>, і сталося так”; вірш 31: And God saw <..., and behold <..>, and the evening $<\ldots>$, and the morning. - "І побачив Бог $<\ldots>$, I ото $<\ldots>$, I був вечір, $\mathrm{i}$ був ранок".

Висновки та перспективи подальших досліджень. Порівняння лексикостилістичних засобів віршів 14-31 АМ ТП і УМ ТП загалом підтвердило висновки, сформульовані в першій частині цього повідомлення [12], про достатньо високий ступінь їхньої схожості. В обох текстах вживаються практично однакові (за незначними 
винятками) марковані лексеми. Суттєвий паралелізм спостерігається також стосовно повторів, інколи видозмінених (включаючи посилений і тавтологічний), персоніфікації, парафраз, вживання афоризмів, іменників в однині у родовому значенні, стилістично забарвлених лексем, риторичного звертання, конструкцій однорідних членів. Лексикостилістичне наповнення в обох текстах є переважно ідентичним, хоча спостерігаються і природні відмінності, зміст яких розглядається далі. Полісиндетон $є$ яскравою ознакою обох текстів, і хоча кількість елементів, що повторюються в них, може варіюватися, така різниця є незначною і не впливає на загальне враження. Градація й ампліфікація в обох ТП застосовуються синхронно (зокрема, у віршах 17 і 18 висхідна градація в обох текстах досягається повтором інфінітивних конструкцій), так само, як і систематичне, хоч і не завжди паралельне вживання архаїзмів або незвичних для відповідного контексту лексем.

До відмінностей порівнюваних текстів можна віднести алітераційний повтор у вірші 10, двофокусний повтор та послаблений полісиндетон у вірші 29 в АМ ТП; посилений дієслівний повтор у рефрені кожного періоду в УМ ТП; повтор у віршах 14-15, де зазначення мети в АМ ТП за допомогою прийменника for дозволяє його застосування, тоді як вживання орудного відмінка іменника у сполученні з дієсловом переходу 3 одного стану до іншого в УМ ТП унеможливлює повтор в принципі. До інших розбіжностей відносяться систематичне вживання дієслова стану (be) в АМ ТП і застосування різних дієслів переходу з одного стану до іншого в УМ ТП; вживання однотипних метафор в АМ ТП там, де в УМ ТП вжито нейтральні лексеми, або, навпаки, використання в УМ ТП слів підвищеного стилю і нейтральність їхніх відповідників в АМ ТП. Розбіжностями між двома текстами є також застосування парцеляції в АМ ТП (вірш 1), унаслідок чого стилістичний акцент падає на парцелят, тоді як в УМ ТП передання того ж фрагмента здійснюється за допомогою парного зв'язку синонімів. Іншими стилістичними фігурами, які застосовувалися лише в одному ТП, є персоніфікація в АМ ТП, та алітерація й асонанс - в УМ ТП (вірші 1112); застосування інфінітивної структури для передачі мети в АМ ТП і віддієслівного іменника в УМ ТП (вірші 14-15); більша варіативність означень (препозитивне, постпозитивне, за допомогою підрядного звороту) та ширший діапазон лексикостилістичних засобів в УМ ТП (вірші 20-23, 30); вживання архаїзму, метафори і синекдохи в АМ ТП (відсутні в УМ ТП) у вірші 29; більша фонетична і лексична різноманітність узагальнювальних означень в УМ ТП (вірш 30).

Загалом можна зробити висновок про дещо більшу варіативність лексикостилістичних засобів в УМ ТП, однак це навряд чи можна розглядати як перевагу останнього, порівняно з АМ ТП, оскільки, як відомо [19], стандарти стилістичної прийнятності різних видів дискурсу мають суттєві відмінності в різних мовах і культурах.

Як і в першій частині цього повідомлення [12], доцільно констатувати, що вивчення відмінностей між лексико-стилістичними ознаками конфесійного стилю англійської та української мов потребують додаткових досліджень на більшому обсязі матеріалу, в чому і вбачаємо перспективу подальшого дослідження. 


\title{
СПИСОК СКОРОЧЕНЬ
}

\author{
АМ ТП - англомовний текст перекладу \\ ТО - текст оригіналу \\ ТП - текст перекладу \\ УМ ТП - українськомовний текст перекладу \\ ФКП - фахова компетентність перекладача
}

\section{СПИСОК ВИКОРИСТАНОЇ ЛІТРАТУРИ}

1. Баранник Д. Х. Період. Українська мова : Енциклопедія. Київ : Вид-во “Українська енциклопедія" імені М. П. Бажана, 2007. С. 472-473.

2. Біблія або Книги Святого Письма Старого й Нового Заповіту. Із мови давньоєврейської й грецької на українську дослівно наново перекладена : пер. І. Огієнка. Київ : Українське Біблійне Товариство, 2009. 1151 с.

3. Великий тлумачний словник сучасної української мови [Уклад. і голов. ред. В. Т. Бусел]. Київ-Ірпінь : ВТФ "Перун”, 2003. 1440 с.

4. Дудик П. С. Стилістика української мови. Київ : Академія, 2005. 368 с.

5. Жук Т. В. Лексичний та синтаксичний повтор в українській народній творчості (на матеріалі українських народних казок): автореф. дис. на здобуття наук. ступеня канд. філол. наук : 10.02.01. Київ, 2005. $21 \mathrm{c.}$

6. Мацько Л. І., Сидоренко О. М., Мацько О. М. та ін. Стилістика української мови : Підручник. Київ : Вища школа, 2003. 462 с.

7. Пономарів О. Д. Стилістика сучасної української мови : Підручник. Київ : Либідь, 1993. $248 \mathrm{c}$.

8. Пуряєва Н. В. Українська церковна титулатура. Мовознавство. 2000. № 2-3. С. 45-54.

9. Черноватий Л. М. Зіставний стилістичний синтаксис конфесійної сфери в англійській та українській мовах. Вісник Харківського нач. ун-ту імені В. Н. Каразіна. Серія "Іноземна філологія. Методика викладання іноз. мов”. Частина I. 2016. № 82. С. 21-28; Частина II. 2016. № 83. C.168-177.

10. Черноватий Л. М. Методика викладання перекладу як спеціальності. Вінниця : Нова Книга, 2013. 376 c.

11. Черноватий Л. М. Особливості перекладу конфесійних текстів в англійській та українській мовах. Людино- й культурознавчі пріоритети сучасного мовознавства: напрями, тенденції та міждисииллінарна методологія : колективна монографія / за ред. К. І. Мізіна. Переяслав-Хмельницький; Кременчук : ПП Щербатих О. В. 2019. C. 362-375.

12. Черноватий Л. М. Лексико-стилістичні ознаки конфесійної сфери в англійській та українській мовах: зіставний аспект. Іноземна філологія. Львів. нац. ун-т ім. Івана Франка. 2020. Вип. 133. С. 201-212.

13. Четайкіна В. Функції біблеїзмів у промовах Джорджа Буша-молодшого. Іноземна філологія. ЛНУ ім. Івана Франка. 2013. Вип. 125. С. 77-83.

14. Шевченко Л. Л. Конфесійний стиль. Українська мова : Енциклопедія. Київ : Вид-во "Українська енциклопедія" імені М. П. Бажана, 2007. С. 284.

15. Шмігер Т. Застосування теорії релевантности в критиці перекладу: “Києво-Печерський патерик” англійською мовою. Іноземна філологія. ЛНУ ім. Івана Франка. 2013. Вип. 125. С. 100-109.

16. Ющук І. П. Українська мова. Київ : Либідь, 2003. 640 с. 
17. Hirsch E. D., Kett J., Trefil J. The Dictionary of Cultural Literacy. Boston-New-York : Houghton Mifflin, 1993. 619 p.

18. King James Bible. URL: Official King James Bible Online.

19. Nida E. Principles of Correspondence. The Translation Studies Reader. Ed. L. Venuti. LondonNew York : Routledge, 2000. P. 126-140.

\section{REFERENCES}

1. Barannyk D. Kh. Period [Period]. Ukrainska mova : Entsyklopediya [The Ukrainian Language : Encyclopedia]. Kyiv : Vyd-vo "Ukrainska entsyklopediia” imeni M. P. Bazhana, 2007. S. $472-473$.

2. Bibliya abo Knyhy Sviatoho Pysma Staroho y Novoho Zapovitu. Iz movy davnoyevreiskoyi y hretskoyi na ukrainsku doslivno nanovo perekladena [Bible or Books of Holy Script of Old and New Testament. Literally translated anew from Old Jewish and Old Greek] / Per. I. Ohiyenka. Kyiv : Ukrainske Bibliyne Tovarystvo, 2009. $1151 \mathrm{~s}$.

3. Velykyi tlumachnyi slovnyk suchasnoyi ukrainskoyi movy [Big Reference Dictionary of the Contemporary Ukrainian Language]. Uklad. i holov. red. V. T. Busel. Kyiv-Irpin : VTF "Perun", 2003. $1440 \mathrm{~s}$.

4. Dudyk P. S. Stylistyka ukrainskoyi movy [Stylistics of the Ukrainian Language]. Kyiv : Akademiya, 2005. 368 s.

5. Zhuk T.V. Leksychnyi ta syntaksychnyi povtor v ukrainskiy narodniy tvorchosti (na materiali ukrainskykh narodnykh kazok) [Lexical and syntactical repetition in Ukrainian folk narration (on the material of Ukrainian folk tales)]: avtoref. dys. na zdobuttia nauk. stupenia kand. filol. nauk [Extended abstract of Candidate's Thesis] : 10.02.01. Kyiv, 2005. $21 \mathrm{~s}$.

6. Matsko L. I., Sydorenko O. M., Matsko O. M. ta in. Stylistyka ukrainskoyi movy [Stylistics of the Ukrainian Language] : Pidruchnyk. Kyiv : Vyshcha shkola, 2003. $462 \mathrm{~s}$.

7. Ponomariv O. D. Stylistyka suchasnoyi ukrainskoyi movy [Stylistics of the Contemporary Ukrainian Language] : Pidruchnyk. Kyiv : Lybid, 1993. 248 s.

8. Puriaieva N. V. Ukrainska tserkovna tytulatura [Ukrainian Church Hierarchy]. Movoznavstvo. 2000. № 2-3. S. 45-54.

9. Chernovatyi L. M. Zistavnyi stylistychnyi syntaksys konfesiynoi sfery v anhliyskiy ta ukrainskiy movakh [Comparative English and Ukrainian Syntax of Confessional Style]. Visnyk Kharkivskoho nats. un-tu imeni V.N.Karazina. Seriya "Inozemna filologiya". Metodyka vykladannia inoz. mov”. Chastyna I [Part 1]. 2016. № 82. S. 21-28; Chastyna II [Part 2]. 2016. № 83. S.168-177.

10. Chernovatyi L. M. Metodyka vykladannia perekladu yak spetsialnosti [Methodology of Teaching Professional Translation and Interpreting]. Vinnytsia : Nova Knyha, 2013. 376 s.

11. Chernovatyi L. M. Osoblyvosti perekladu konfesiynykh tekstiv v anhliiskiy ta ukrainskiy movakh [Specifics of translating confessional texts in English and Ukrainian]. Liudyno- $i$ kulturoznavchi priorytety suchasnoho movoznavstva: napriamy, tendentsii ta mizhdystsyplinarna metodolohiya : kolektyvna monohrafiya / za red. K. I. Mizina [Human and Culture Studies Priorities in Modern Linguistics: Trends, Tendencies and Interdisciplinary Methodology: multi-authored monograph / ed. by K. I. Mizin]. Pereyaslav-Khmelnytskyi; Kremenchuk: PP Shcherbatykh O.V. 2019. S. 362-375.

12. Chernovaty L. M. Leksyko-stylistychni oznaky konfesiynoi sfery v anhliyskiy ta ukrainskiy movakh: zistavnyi aspekt. [Lexical and stylistic features of confessional sphere in English and Ukrainian: a comparative aspect]. Inozemna Philologia. LNU im. Ivana Franka. 2020. Vyp. 133. S. 201-212. 
13. Chetaikina V. Funktsiyi bibleizmiv u promovakh Dzhordzha Busha-molodshoho [The functions of Biblical words and phrases in the speeches of George W. Bush]. Inozemna Philologia. LNU im. Ivana Franka. 2013. Vyp. 125. S. 77-83.

14. Shevchenko L. L. Konfesiynyi styl' [Confessional style]. Ukrayinska mova: Entsyklopediya [The Ukrainian Language: Encyclopedia]. Kyiv : Vyd-vo "Ukrainska entsyklopediyia" imeni M. P. Bazhana, 2007. S. 284.

15. Shmiher T. Zastosuvannia teoriyi relevantnosty v krytytsi perekladu: "Kyievo-Pecherskyi pateryk" anhliyiskoiyu movoiu [Applying relevance theory to translation criticism: The Paterik of the Kyivan Caves Monastery in English]. Inozemna Philologia. LNU im. Ivana Franka. 2013. Vyp. 125. S. 100-109.

16. Yushchuk I. P. Ukrainska mova [The Ukrainian Language]. Kyiv : Lybid, 2003. $640 \mathrm{~s}$.

17. Hirsch E. D., Kett J., Trefil J. The Dictionary of Cultural Literacy. Boston-New York : Houghton Mifflin, 1993. 619 p.

18. King James Bible. URL: Official King James Bible Online.

19. Nida E. Principles of Correspondence. The Translation Studies Reader. Ed. L. Venuti. LondonNew York : Routledge, 2000. P. 126-140.

Стаття надійшла до редколегії 28.06.2021

Прийнята до друку 11.07.2021

\title{
LEXICAL AND STYLISTIC FEATURES \\ OF CONFESSIONAL SPHERE IN ENGLISH AND UKRAINIAN: A COMPARATIVE ASPECT (PART 2)
}

\section{Leonid Chernovaty}

\author{
V. N. Karazin Kharkiv National University, \\ 4, Svoboda Square, Kharkiv, Ukraine, 61022 \\ leonid.m.chernovaty@meta.ua
}

The paper deals with the contrastive analysis of the Ukrainian (Ivan Ohiyenko) and English (King James Bible) translations of the Old Testament (Genesis, Chapter 1) with the purpose to establish their comparative lexical and stylistic features.

The assessment of the stylistic devices in the Ukrainian (UTT) and English (ETT) target texts proves a high degree of their similarity. There is a considerable parallelism in the use of repetition, paraphrase, aphorisms, generic nouns, stylistically coloured lexemes, rhetorical address and homogenous elements' structure. The polysyndeton is a distinctive feature of both texts as well as gradation and a systematic use of archaic or unusual words.

The dissimilarities of the two texts include alliterative repetition in verse 10, a double-focus repetition and a weakened polysyndeton in verse 29 in ETT, repetition in ETT (verses 14-15) which appeared to be impossible in UTT due to the specific structure used there and the strengthened verb repetition in the refrain of each period in UTT. Other distinctions include a systematic use of the state verb (be) in ETT, whereas the UTT utilizes a range of dynamic verbs indicating the transition from one state to another; the use of two monotypic metaphors in ETT, as compared to neutral lexemes in UTT; or, conversely, the ETT counterpart of an elevated style word is stylistically neutral in UTT. Another divergence is the use of parceling in ETT, 
which shifts the stylistic emphasis to the parceled fragment, while in the UTT the preference is given to the double synonymic structure; the use of archaism, metaphor and synecdoche in ETT whereas they are absent in UTT. Other unilaterally used stylistic devices include personification in ETT versus alliteration and assonance in UTT; the use of an infinitive stricture in ETT and a verbal noun in UTT to render purpose; greater variability of attributes (prepositional, postpositional, subordinate clauses), as well as lexical stylistic means in UTT; greater phonetic and lexical diversity of generalizing attributes in UTT. Overall, a somewhat greater variety of lexical stylistic means in UTT may be assumed, although it can hardly be regarded as the latter's advantage because the standards of stylistic acceptability substantially vary in different languages and cultures. The scope of further research is outlined.

Key words: English and Ukrainian languages, Bible (Genesis), comparative stylistics, comparative lexicology, confessional style, teaching translation and interpreting, comparative lexical and stylistic analysis, lexical and stylistic features. 